University of Nebraska - Lincoln

DigitalCommons@University of Nebraska - Lincoln

Agronomy \& Horticulture -- Faculty Publications

Agronomy and Horticulture Department

3-1950

\title{
Monolith Method of Root-Sampling in Studies on Succession and Degeneration
}

J. E. Weaver

University of Nebraska-Lincoln

John Voigt

Follow this and additional works at: https://digitalcommons.unl.edu/agronomyfacpub

Part of the Plant Sciences Commons

Weaver, J. E. and Voigt, John, "Monolith Method of Root-Sampling in Studies on Succession and Degeneration" (1950). Agronomy \& Horticulture -- Faculty Publications. 446.

https://digitalcommons.unl.edu/agronomyfacpub/446

This Article is brought to you for free and open access by the Agronomy and Horticulture Department at DigitalCommons@University of Nebraska - Lincoln. It has been accepted for inclusion in Agronomy \& Horticulture -Faculty Publications by an authorized administrator of DigitalCommons@University of Nebraska - Lincoln. 


\title{
MONOLITH METHOD OF ROOT-SAMPLING IN STUDIES ON SUCCESSION AND DEGENERATION ${ }^{\mathrm{I}}$
}

\author{
J. E. WEAVER AND JOHN W. VOIGT
}

\section{Introduction}

A new method has been devised by which a complete sample of an entire root system may be taken from soil surface to maximum depth of penetration. The roots are separated from the soil without injury to them or displacement of individual roots from their natural position. They are examined in the laboratory in relation to the various horizons of the soil profile. Monoliths I 2 inches wide, 3 inches thick, and 3-5 feet in depth are taken from the walls of trenches made in selected pure stands of each species. Roots are obtained from the monolith by a system of soaking and gentle washing. A special technique is used in mounting. Lighting for photographing is by electro-flash units. The root system is sectioned so as to obtain the oven-dry weight for each 6 inches or foot in depth as well as for each major soil horizon. A brief description of the method may be found in Science (7) and a complete one in Ecological Monographs (8).

This new method, which permits the studying of the intimate relations of

\footnotetext{
${ }^{1}$ Contribution from the Department of Botany, University of Nebraska, no. 154 .
}

roots and soils and of measuring root production quantitatively at various soil levels, has been used extensively. Descriptions have been made of the profiles of twenty soil types, from which thirteen species (and about fifty monoliths) have been taken. The chief purpose of these studies was to examine soil-root relationships in various soil types (8). The present paper is concerned with results obtained by a modification of the method and its use in studying succession and degeneration of vegetation.

\section{Observations}

\section{MODIFICATION OF METHOD}

A modification of the original method consisted in increasing the width of the monolith to 2.5 feet, so that a more continuous view of the underground plant parts might be obtained. This necessitated obtaining the soil and roots in sections 3 feet long and 3 inches thick where roots extended deeply. The lower section was taken from the vertical wall of a trench, directly below the upper one. To prevent the soil at 3 feet depth from crumbling when the bottom of the upper frame holding the monolith was fitted in place, 


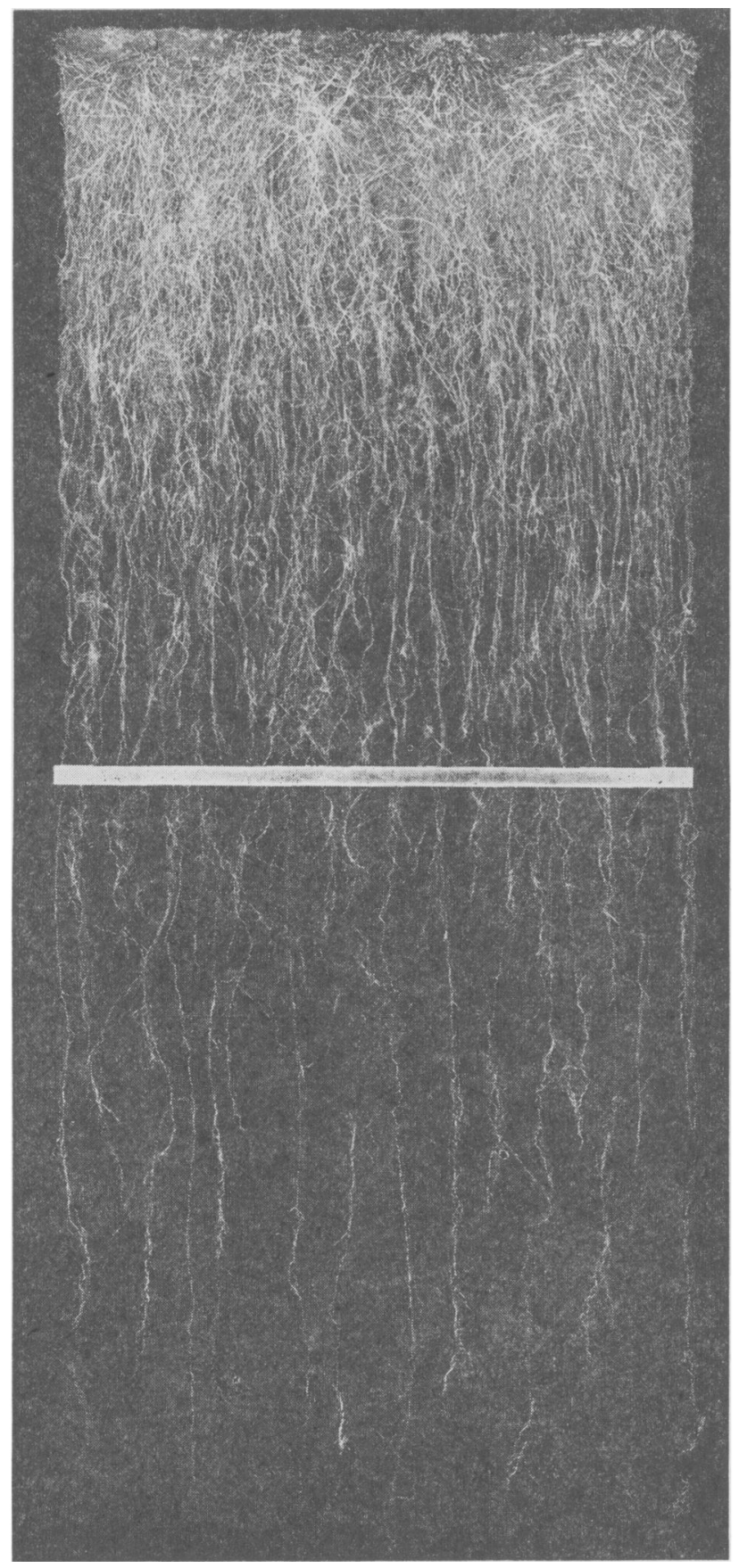

Fig. I.-Root system of Andropogon furcatus taken from the two sections of a monolith, each 2.5 feet wide, 3 inches thick, and 3 feet long. White strip covers 37 th inch, which is lost in obtaining sample. Note gradual decrease in density of root mat with depth and very uniform distribution of roots at any level. 
a straight-edged board was placed horizontally against the trench wall at exactly 37 inches in depth and fastened securely in place while the upper monolith was

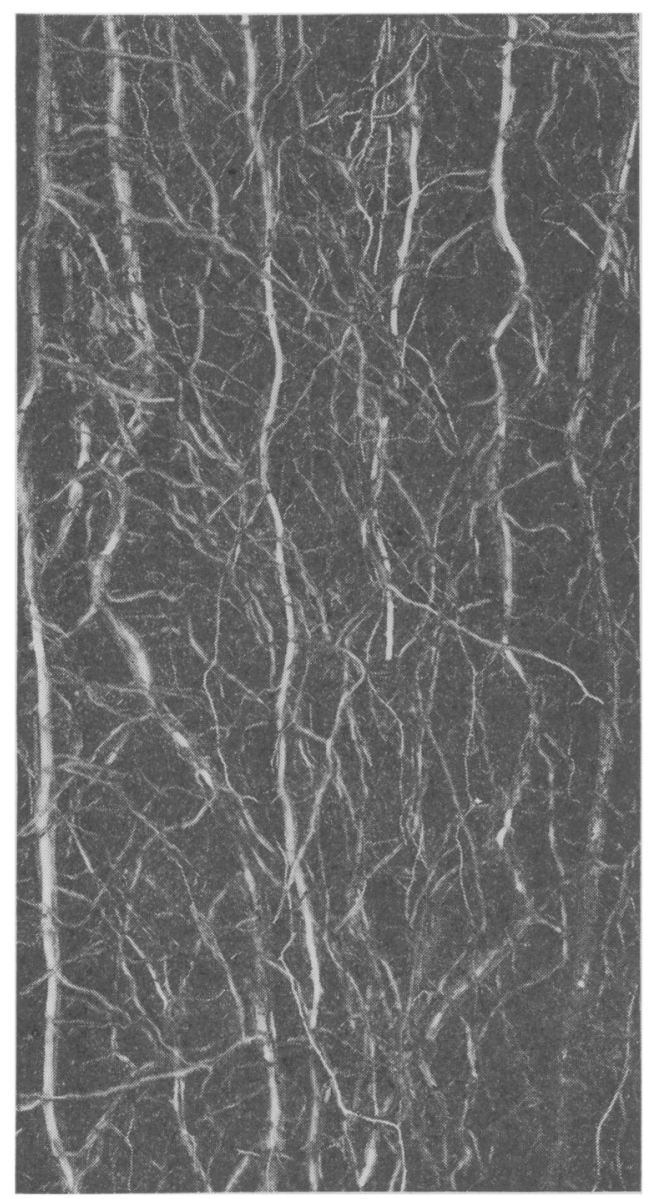

FIG. 2.-Portion of root system shown in figure $\mathbf{I}$. Roots are natural size, and branches are in normal position; taken at depth of $24^{-29}$ inches.

being removed. Thus, only $\mathrm{I}$ inch of soil and roots was lost where the soil was removed to make room for the lower end of the upper monolith frame. In mounting the roots and in the photographs, this space was occupied by a thin strip of wood (fig. I).
REPLACEMENT OF BIG BLUESTEM BY KENTUCKY BLUEGRASS

On an area of low, nearly level, but well-drained land near Lincoln, Nebras$\mathrm{ka}$, an excellent bluestem prairie occurred. This was the 50-acre tract about 3 miles northeast of Havelock, a suburb of Lincoln, which was intensively studied by WeAver and DarLand over the period r943-1946, inclusive (6). A chief dominant in this rich, alluvial Wabash silt loam was big bluestem (Andropogon furcatus). It frequently occurred in local pure stands of sod. The foliage normally attained a height of 3 feet, but the coarse flower stalks were often 6-7 feet high The uniformity of the grass above ground was no more marked, however, than that of the coarse roots in the soil (fig. I). Although there was some crisscrossing of roots in the upper soil, the general direction was vertically downward. The upper or A horizon (o-24-in. depth) contained the bulk of the root mass. In the subsoil ( $C$ horizon-24-4I inches) the roots decreased rapidly in number; but many extended deeply, even to 6 feet (fig. I).

This wonderfully developed root system loses much in detail in photographing it in its entirety. Detail of the root pattern is shown in figure 2 . The coarse main roots are $2-3 \mathrm{~mm}$. in width. The glistening white stele may be seen through the somewhat transparent cortex.

Decrease in root weight with depth was very marked but was about normal for this species. In the surface 4 inches the roots themselves often furnished about half the total weight, rhizomes and stem bases in the soil being, as usual, about equally heavy (9). Despite the small amount of the lower half of the root system (only $2.8 \%$ of the whole), this 
portion was undoubtedly active in absorption far out of proportion to its weight. During drought it enabled this species to remain alive where numerous less deeply rooted grasses died (5) (table I).

As a result of grazing this prairie, big bluestem decreased in vigor, waned, and died, and like other prairie grasses it was replaced by a nearly continuous sod of Kentucky bluegrass (Poa pratensis). This occurred during a period of only a few years (I943-1946) and was the result of too early grazing in spring and overstocking (6). The roots of a representative sample of the underground parts of bluegrass were secured for study. The great bulk of the root mass $(89.9 \%)$ occurred in the surface foot of soil and nearly all the remainder in the second foot. Only rarely did a root end extend beyond 3 feet in depth (fig. 3). The roots are very

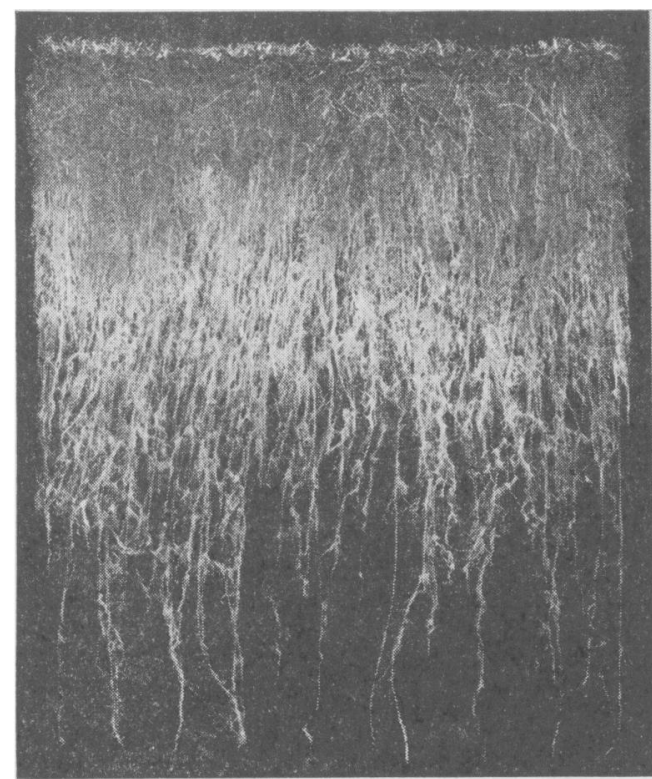

fine and draw intensively upon the surface soil for moisture and nutrients. Their distribution and weight at the several depths are shown in table $\mathrm{I}$.

The sOIL PROFILE.-The remarkably uniform distribution of the roots of big

TABLE 1

OVEN-DRY WEIGHT OF ROOTS AND PERCENTAGE OF DRY WEIGHT AT SEVERAL SOIL DEPTHS

\begin{tabular}{|c|c|c|c|c|}
\hline \multirow{2}{*}{$\begin{array}{l}\text { DEPTH } \\
\text { (IN.) }\end{array}$} & \multicolumn{2}{|c|}{$\begin{array}{l}\text { ANDROPOGON } \\
\text { FURCATUS }\end{array}$} & \multicolumn{2}{|c|}{$\begin{array}{c}\text { PoA } \\
\text { PRATENSIS }\end{array}$} \\
\hline & $\begin{array}{l}\mathrm{Wt} . \\
(\mathrm{gm} .)\end{array}$ & $\begin{array}{r}\% \\
\text { wt. }\end{array}$ & $\begin{array}{l}\text { Wt. } \\
\text { (gm.) }\end{array}$ & $\begin{array}{l}\% \\
\text { wt. }\end{array}$ \\
\hline$o-6 \ldots \ldots$ & 62.87 & 69.0 & 42.55 & 76.5 \\
\hline 6-I 2. & I 2.59 & I 3.8 & $7 \cdot 44$ & I 3.4 \\
\hline I $2-24 \ldots \ldots$ & $9 \cdot 79$ & 10. 7 & $4.8 I$ & 8.7 \\
\hline $24-36 \ldots \ldots$ & $3 \cdot 3^{8}$ & $3 \cdot 7$ & $0.8 \mathrm{I}$ & I. 4 \\
\hline $36-48 \ldots \ldots$ & I. 23 & I. 4 & $\ldots \ldots$ & $\ldots \ldots \ldots$ \\
\hline $48-60 \ldots$ & 0.80 & 0.9 & $\ldots \ldots$ & $\ldots \ldots$ \\
\hline $60-72 \ldots \ldots$ & 0.49 & 0.5 & $\ldots \ldots$ & $\ldots \ldots \ldots$ \\
\hline Total.... & 9 I. I 5 & 100.0 & $55.6 \mathrm{I}$ & 100.0 \\
\hline
\end{tabular}

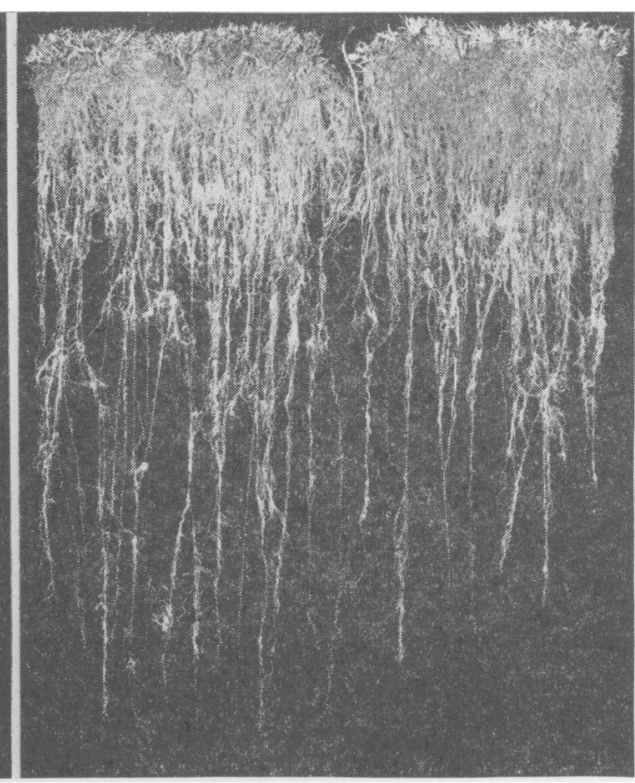

Figs. 3-4.-Fig. 3 (left), root system of Poa pratensis showing relatively shallow depth to which roots penetrate and concentration of mass of roots in surface soil. Fig. 4 (right), root development of Bouteloua gracilis (left) and P. pratensis (right) in old, upland pasture near Lincoln, as shown in monolith 3 feet deep. Total root systems weighed only $28.2 \mathrm{gm} ., 82 \%$ of which occurred in surface 6 inches of soil. 
bluestem to great depths is surprising when the soil profile is examined. This Wabash silt loam is an alluvial soil. ${ }^{2}$ It is also a young soil without horizon differentiation to a depth of $4 \mathrm{I}$ inches, except the accumulation of noticeable amounts of organic matter to a depth of 24 inches. Below a depth of $4 \mathrm{I}$ inches there is an $\mathrm{X}$ layer or buried soil. It has horizon development comparable with mature soils. The $\mathrm{X}$ layer represents material of a different age and deposition from that in which the present soil at the surface has developed. It has undergone some modification since it was buried by the younger material (perhaps I 50 years ago), but the several horizons are clearly defined. The lower, $\mathrm{XB}_{3}$, horizon is a strongly developed horizon of lime carbonate accumulation.

The horizons are as follows:

\begin{tabular}{|c|c|c|}
\hline$A$ & 4 in. & Surface soil \\
\hline $\mathrm{C}$ & $24-4 \mathrm{I}$ in. & $\begin{array}{l}\text { Subsoil or parent material of } \\
\text { the present soil }\end{array}$ \\
\hline
\end{tabular}

$\mathrm{XA}_{\mathrm{I}} \quad 4^{-} \mathrm{I}^{-5} \mathrm{in}$. Surface soil of buried soil

$\mathrm{XB}_{\mathrm{I}-2}$ 50-66 in. Leached subsoil of buried soil

$\mathrm{XB}_{3} \quad 66-72$ in. Strongly calcareous subsoil of buried soil

\footnotetext{
Horizon Depth Description (color is that of dry soil)

$\mathrm{A}_{\mathrm{I}-\mathrm{I}} \quad \mathrm{O}^{-} \mathrm{I}$ Dark gray, friable, platy mulch silt loam; pH 6.5

$\mathrm{A}_{\mathrm{I}-2} \quad \mathrm{I}-6$ Dark gray silt loam; friable; granular; $\mathrm{pH} 6.5$

$\mathrm{A}_{1-3}$ 6-24 Grayish-brown silt loam; friable; coarse; granular or nuciform; pH 6.5

$\mathrm{C}_{\mathrm{I}^{-1}}$ 24-34 Light brownish-gray, friable silt loam; somewhat stratified with darker lenses; irregular medium blocky; pH 6.5

$\mathrm{C}_{\mathrm{I}-2} \quad 34^{-4}$ I Same color as layer above, but silty clay loam showing a little

${ }^{2}$ The soil profile was described by $B$. $H$. Williams of the Division of Soil Survey, U.S. Department of Agriculture, and the Conservation and Survey Division, University of Nebraska.
}

more stratification; $\mathrm{pH} 6.5$. The strata in this layer are separated by a film of light gray silt and very fine sand

$\mathrm{XA}_{\mathrm{I}} \quad 4^{\mathrm{I}}-50 \quad$ Black clay; large blocky; plastic when wet; hard when dry; $\mathrm{pH}$ 6.5

$\mathrm{XB}_{\mathrm{I}}$ 50-60 Grayish-brown, blocky silty clay; moderately hard when dry; moderately plastic when wet; $\mathrm{pH} 7.0$

$\mathrm{XB}_{2}$ 60-66 Grayish-brown, silty clay loam; blocky; moderately hard when dry; moderately plastic when wet; $\mathrm{pH} 7.0$

$\mathrm{XB}_{3} \quad 66-72$ Light yellowish-brown, nuciform, heavy silt loam; friable; calcareous, including streaks and seams of segregated lime carbonate; $\mathrm{pH} 7.5$

The rich A horizon of the buried soil seemed to have no visible effect upon root development or distribution. Where the new soil is shallower, root development of certain grasses has been found to be greater in the old topsoil.

Significance of CHANGE.-The effects of the degeneration of climax prairie into bluegrass pasture have been ascertained aboveground. The change from prairie to bluegrass was a sign both of degeneration and of decreased forage production. The annual yield under grazing was obtained by measuring the monthly yield from early spring until late fall. This was done by means of large portable exclosures. The prairie grasses, among which big bluestem was most abundant, produced $39-99 \%$ more forage than bluegrass. Moreover, bluegrass is a less palatable and less desirable pasture grass, partly because it often dries and is more or less dormant in midsummer.

It was in one of the exclosures, left permanently in place since I946, that the sample of big bluestem roots was taken 
in June, I949. The bluegrass was secured outside the exclosure at the same time.

Knowledge of the root systems adds much to an understanding of the ecology of these grasses and the thousands of square miles of pasture lands which each occupies. Only the upper portion of the soil is utilized by bluegrass. Often it is more shallowly rooted than in this pasture; only rarely is it deeper. During the dry climatic cycle of I934-I940 in the Midwest, practically all bluegrass pastures of eastern Nebraska succumbed to drought. They remained intact only along streams where the water table was high. In Iowa, also, great damage occurred. Extensive soil sampling during the drought revealed that the soil under bluegrass had much available water below 2.5 feet. With such subsoil moisture and the nutrients of deep, rich, virgin soils, big bluestem maintained life and often thrived, while the more shallowly rooted bluegrass died.

Native bluestem pastures often almost exclude the invasion of weeds until the grasses are largely replaced by bluegrass. Then the entrance of invading ruderals is rather easily accomplished. Once they extend their roots below the 2-foot level, competition underground is greatly decreased. It is then that the ragweeds (Ambrosia artemisifolia and A. psilostachya), ironweed (Vernonia baldwini), and a host of other species thrive. Since I 946 ironweed and buckbrush (Symphoricarpos occidentalis) alone have spread so widely and are so densely aggregated in this experimental pasture that the yield of bluegrass has been decreased by about one-third.

\section{SUBSERES IN UPLAND PASTURE}

Bluegrass pastures represent a third or fourth stage in the degeneration of true prairie under injudicious management.
It is a common pasture type. But as one approaches the western edge of true prairie, as at Lincoln, blue grama (Bouteloua gracilis) often takes the place of bluegrass or, frequently, shares the area with it. The root relations of these grasses in Carrington silty clay loam are shown in figure 4. Development of blue grama is scarcely better than that of the bluegrass, although the roots do penetrate somewhat more deeply. Both species occurred as isolated patches with bare soil between, except for the part occupied by low-growing pasture weeds. These grasses grew in an old soil developed on glacial drift. It was very compact. The dark grayish-brown, granular, heavy silty clay loam of the A horizon extended to a depth of only 7 inches. The subsoil of similar color and texture (B horizon) was only ${ }_{5} 5$ inches deep. Below the solum $(22-36$ in.), the parent material consisted of dark yellowish-brown clay with a blocky structure loosely filled with small rocks and pebbles. Only a few of the longest roots of blue grama extended to a depth of 3 feet.

This root development of these grasses on upland is not unusual. Nor is the replacement of the deeply rooted bluestems and other climax grasses by more shallowly rooted ones uncommon. In a native pasture of 2 Io acres near Lincoln, three distinct pasture types or stages in degeneration are clearly evident. They have resulted partly from distance to the water supply, which is near the southern end of the mile-long pasture, but also from the lesser accessibility to the northern end of the pasture because of steep slopes $(9-\mathrm{II} \%)$ and deep ravines. This distant portion is, after 46 years of grazing, still near the prairie stage. Conversely, the southern part, on similar rolling hills, has been reduced to a low-grade subsere dominated largely by bluegrass 
and blue grama. An intermediate stage with about half bluestems and half bluegrass occupies the central part of the pasture. The Carrington silt loam is fairly uniform throughout, but it is deeper than the soil type just described.

Monoliths of soil were taken in representative areas of each grade of pasture. In the high-grade type the depth of the dominant little bluestem (Andropogon scoparius) was 42 inches, and the total root weight was $84.3 \mathrm{gm}$. In the midgrade samples the weakened little bluestem was 36 inches deep and Kentucky bluegrass 24 inches. Combined root weight was $68.4 \mathrm{gm}$. When the bluegrass and blue grama were sampled in the lowgrade pasture, where all prairie grasses had disappeared, the depth of bluegrass was again 24 inches, that of blue grama was 32 . Dry weight of the root sample was only 35.I gm. Thus, if the root weight in high-grade pasture is considered 100\% (although even here the roots were not so heavy as those of ungrazed prairie), those in the mid-grade were $8 \mathrm{r} \%$ as heavy. Those in the bluegrassblue grama subsere had been reduced to $42 \%$.

\section{ROOT DISTRIBUTION BETWEEN BUNCHES}

Among such sod-forming grasses as buffalo grass (Buchloe dactyloides) and western wheat grass (Agropyron smithii), a monolith $\mathrm{I} 2$ inches wide gives one accurate information on the general appearance and the interrelationships underground. But where monoliths I2 inches wide are taken directly beneath a bunch of little bluestem, prairie dropseed (Sporobolus heterolepis), or other bunch grasses, there is still some doubt as regards amount of root materials between the bunches. In earlier work, where the trench and hand-pick method was employed (I-4), information on direction and extent of lateral spread was recorded. But this gave no quantitative answer to the question. Before the 30-inch-wide monolith was employed, all samples of roots were obtained directly below the bunch.

This problem has now been solved, and quantitative data have been obtained for little bluestem and certain other prairie grasses. Root distribution in a pure climax stand of little bluestem in Sharpsburg silty clay loam near Lincoln is shown in figure 5 . The sample for the monolith was selected upon the basis of an approximately normal distance between bunches. The background and foreground where the monolith was taken had approximately the same distribution of bunches as the upper surface of the monolith in figure 5. In the sample the several bunches at the soil surface occupied 12 of the 30 inches of width, and interspace between bunches the remaining I 8 inches. The root mat was cut vertically, so that all root material in the 2 feet below the bunches could be weighed separately from that between them. Since the stem bases and short rhizomes were concentrated directly beneath the bunch in the surface soil, the upper ? inches of the entire mat was discarded. Moreover, the root mass was cut horizontally at a depth of $\mathrm{I} 2$ inches so as to separate all material in the second foot from that in the first. Maximum lateral spread of the roots beyond the outer edge of the crown was $5^{-\mathrm{I} 2}$ inches; it was often as great and sometimes greater than that in the surface 3 inches of soil.

Total oven-dry weight of material under the bunches at the $3^{-1}$-inch depth was $10.98 \mathrm{gm}$. or $0.9^{2} \mathrm{gm}$. per inch in width of the 3 -inch-thick mat. Between the bunches it was I $4.98 \mathrm{gm}$. or $0.83 \mathrm{gm}$. per inch. At the I 2-24-inch level the total weights were 0.48 and $0.42 \mathrm{gm}$. per inch, 
respectively. Some roots, of course, entered the back of the monolith, and others penetrated into the front surface. According to these results, the upper soil layer in the interbunch areas $\left(3^{-I} \mathrm{I} 2 \mathrm{in}\right.$.) was $90 \%$ as well occupied by roots, and the soil surface. This habit of growth occurs even under mowing and may account in part for the paucity of interstitial species in pure stands of this dropseed. Two bunches, 8 and 4 inches in width, were ro inches apart in the mono-

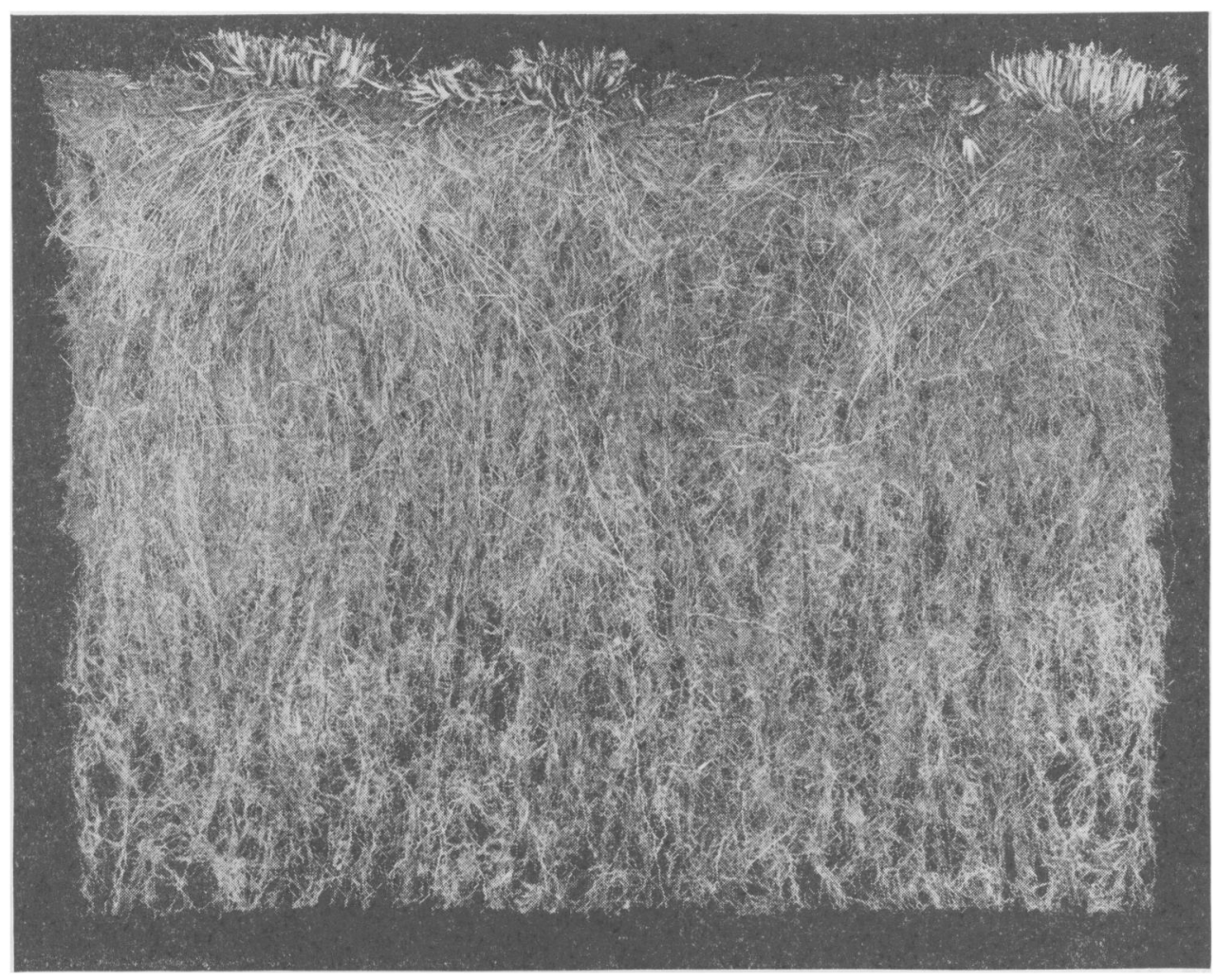

Fig. 5.-Roots of Andropogon scoparius in monolith of soil 30 inches wide, 3 inches thick, and 2 feet deep, taken from climax true prairie.

the second foot $87 \%$ as well filled, as that portion directly beneath the bunches.

A monolith of similar dimensions was taken in a practically pure stand of prairie dropseed only a little distant in the same soil type. This is a grass of even more pronounced bunch habit than little bluestem. The dense mat of long, outstretched leaves forms a continuous mulch between the bunches, the crowns of which are elevated $1-3$ inches above lith. The remaining surface was mostly without other vegetation. Examination showed that some rcots spread 5 inches from the bunch in the surface inch of soil; at 2 inches depth many spread 5-7 inches. Weight of roots per inch between the crowns of the bunches at $3^{-1} 2$ inches depth was $82 \%$ as great as that directly beneath the crowns; in the 12-24-inch depth it was $108 \%$ as great as that beneath the bunches. 
One may conclude from these and similar data that in stabilized true prairie, where interstitial species of grasses and forbs occur between the bunch grasses, the density and weight of the underground parts are quite uniform. It is believed that this varies scarcely more in uniformity than the root masses under stands of sod-forming grasses. But this uniformity of root distribution does not occur generally in subseres, even those in advanced stages of development.

\section{COMPETITION UNDERGROUND IN STAGES OF SUCCESSION}

One part of the prairie near Lincoln, used for ecological studies for many years, is a subsere resulting from a quarter-century of grazing. Livestock have now been excluded from this portion for a period of I I years, and the vegetation is nearly in a prairie climax. One chief difference is the relict patches of Kentucky bluegrass which still exist, although surrounded by big bluestem. In late summer, despite the excellent development of bluegrass, these areas appear as depressions in the 3 -foot foliage cover of big bluestem. The underground relationships of these species were examined in June by means of wide monoliths (fig. 6).

The density of the roots in this very deep, rich, Judson silt loam was greater even than that described earlier from Wabash silt loam. This soil with a 20inch-deep A horizon is developed in silty colluvium. It lies between a soil type developed from loess on the upland and Wabash silt loam of the bottomlands. The wonderful network of bluegrass roots was $24 \%$ heavier than that from a similar soil volume in the Wabash soil. Those of big bluestem were $34 \%$ heavier. The network of bluegrass roots rapidly became thinner below 2 feet; a few roots were 4 feet deep. But some roots of big bluestem penetrated into the sixth foot of soil.

Aboveground the overtowering big bluestem cast a dense shade. Only $\mathrm{I}-3 \%$ of light reached the soil beneath its foliage, and no bluegrass occurred there. At the edge of the bluestem sod, bluegrass received light of low intensity, and where the tall grass lodged over the bluegrass the intensity was often reduced to $\mathrm{\%} \%$ or less. Examination of figure 6 shows that, although no bluegrass roots occur beneath the big bluestem, some of the roots of the bluestem have entered the soil under the bluegrass sod. In fact, there seemed to be a tendency for many of the roots to turn away from the soil area directly below the bluestem sod (which extended many feet to the right of fig. 6) and grow toward the area of bluegrass.

Following this clue, careful examination of root spread was made at many points along the tension lines between the two species. Invasion of big bluestem into the root mat of bluegrass occurred frequently and was often pronounced (fig. 7). Root behavior of switchgrass (Panicum virgatum) was then studied. It was found to invade adjacent patches of bluegrass in a similar manner (fig. 8). It is of interest that in both of these species invasion by lateral spreading of roots, especially in the upper 2 feet of soil, was I 2-24 inches in advance of the crown, the spread of which was determined by development of rhizomes.

Nearly all the previous studies of roots of native species made by the senior writer and his students were in nearly stabilized or climax vegetation where plant populations were dense. Although the lateral spread of the roots was examined, measured, and recorded, it was usually not found to be great, and the plant, especially grass, presented a very 
symmetrical pattern. This was probably because of a rather uniform habitat resulting from competition for water and nutrients. For example, twelve to eighteen separate lots of big bluestem and switchgrass had been studied in various habits. The wide monolith offers a means not only of presenting clearly differences in root distribution but it is also a quantitative method of expressing these differences. Sometimes the cause of the success of a particular species in

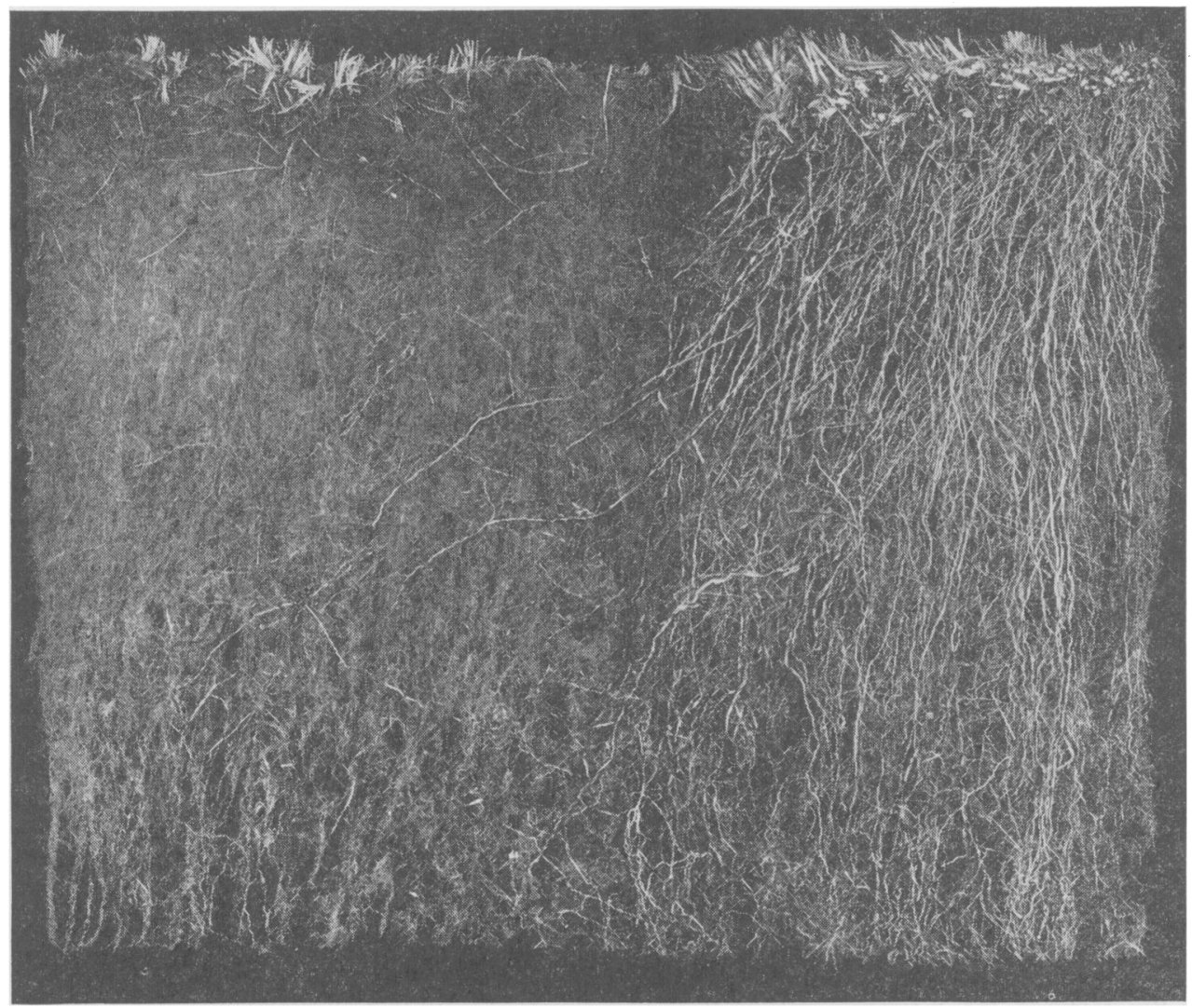

Fig. 6.-Roots of Poa pratensis (left) and Andropogon furcatus (right) from monolith 2 feet deep in Judson silt loam. Note great difference in fineness of roots and tendency of some big bluestem roots to spread downward and outward under bluegrass.

soils, but not one exhibited a root behavior such as has here been recorded in subseres in two very different soil types. Exceptions to this uniformity of pattern were found, of course, in thinly populated areas such as gravel slide and shifting sand and on much-eroded loess hills.

It would seem clear from these findings that much is to be learned in a study of succession by an examination of the root competition and its role in succession may be traced to adjustments of the root system to soil horizons at considerable depth.

\section{Adjustment of Root SYSTEM to SOIL CONDITIONS}

The soil has marked effects upon the root habits of plants (8). This is especially noticeable where the vegetation 
develops upon soils with claypans. The preceding examples are of roots developed on zonal soil types in Prairie soil. But intrazonal soils also occur in placessoils with one or more horizons overde-
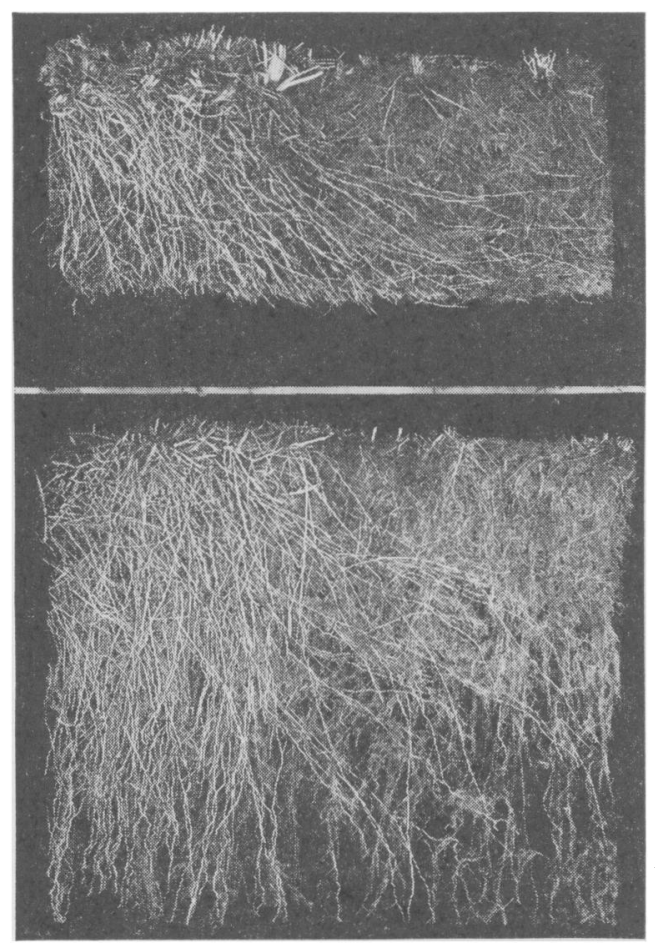

IIGs. 7-8.-Fig. 7 (above), roots from block of soil 17 inches wide, 3 inches thick, and 7 inches deep, showing lateral spread of roots of Andropogen furcatus far into territory occupied at soil surface by Poa pratensis. Fig. 8 (below), roots of Panicum virgatum (left) and Poa pratensis (right) from monolith 2.5 feet wide and 2 feet deep. Note wide spreading of coarse roots of tall Panicum into area of bluegrass far beyond rhizomes in surface soil.

veloped and in marked contrast to the "normal" or zonal soil. Small areas of such soils as Crete silty clay loam with a marked claypan occur on certain hillsides in grassland adjoining the experimental prairie 3.5 miles northwest of the University of Nebraska. Such areas, widely scattered in the Prairie and Chernozem soil zones in eastern Nebraska, are of much interest from the viewpoint of plant succession. Many of them were clothed with bluestems before the great drought (I934-I940); but during the widespread invasion which followed the drought, western wheat grass moved into these places following the death of the bluestems. This grass seems to be better adapted to these soils than any other species of the true prairie, for, despite many years of normal or above-normal rainfall, it prevails in nearly pure stands against all invaders.

Because of the great difficulty in securing samples in claypan soils, a monolith I 2 inches wide was used. Wheat grass has very long roots, often $7-8$ feet in extent. For the purpose of showing the essential features in root-soil relations, however, only 6 feet of the root system was required (fig. 9). The photograph is large enough to show much detail, and the rcot system, excavated in June, I949, is typical of many others from soils with claypans.

Root development was similar to that in a zonal scil in the first $\mathrm{I} 3$ inches or A horizcn. The scil was mellow and granular in structure and nearly neutral in reaction ( $\mathrm{pH}$ 6.8). Both water and roots penetrated easily. The 480 main roots and their branches formed a dense mass.

At I 3 inches depth there was a very abrupt transition to a blocky prismatic structure with a $\mathrm{pH}$ value of 6.6. Clay content increased rapidly with depth, and the soil was extremely hard when dry. Vertical prisms 3-4 inches in diameter were often five- or six-sided and 8-1 2 inches long. They were sometimes broken by somewhat horizontal cracks. In digging the trench, this $\mathrm{B}$ horizon ( $13-28$ in.) was removed only after much labor.

Roots were distinctly fewer in the $B$ horizon. Only about I50 entered this claypan, and the number decreased to 68 


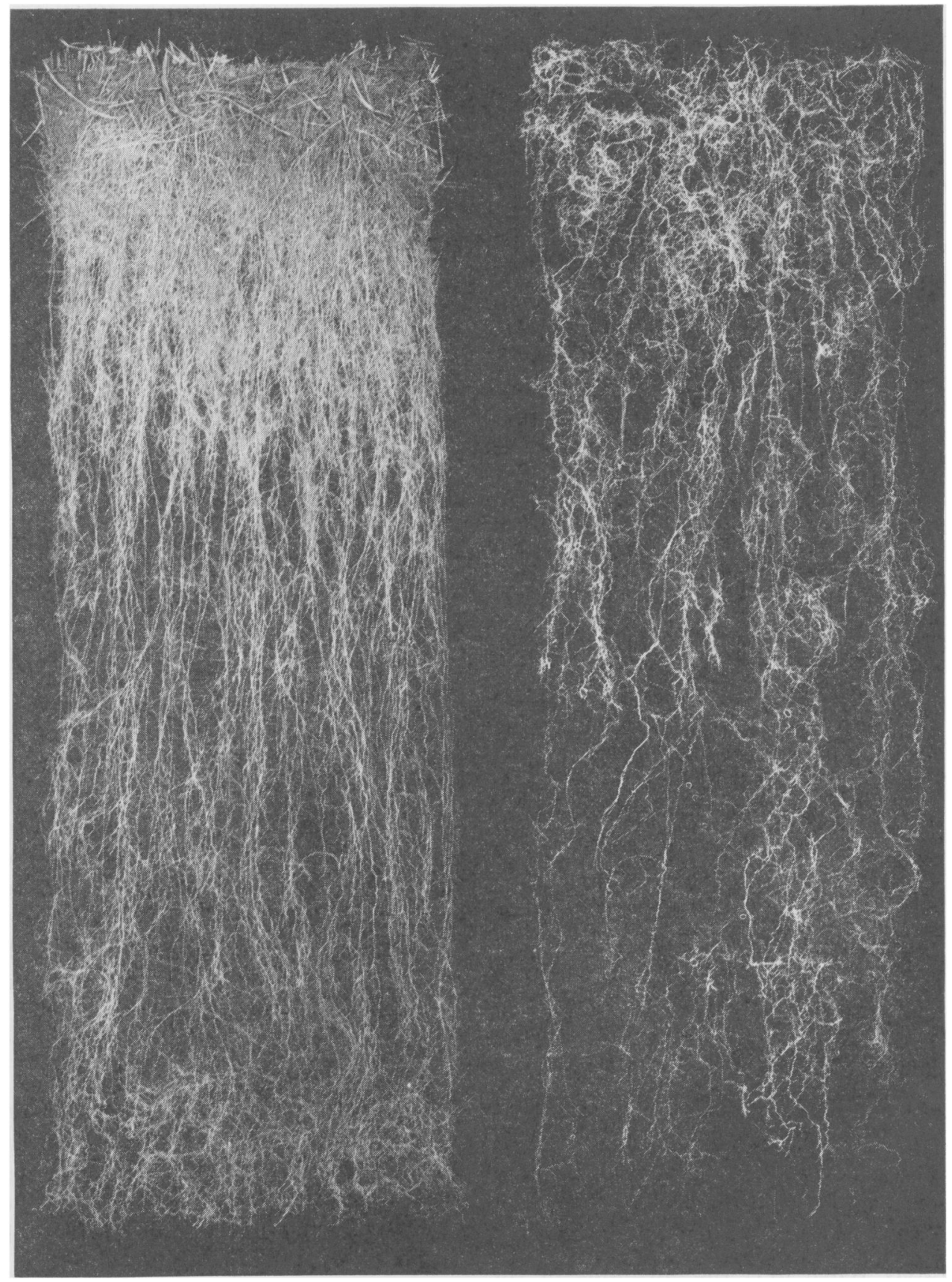

FIG. 9.- Two sections of Agropyron smithii I 2 inches wide taken to 3 feet in depth (left), and $3-6$ feet in depth (right). Note dense mat of roots from granular soil of A horizon (0-1 3 in.) and more open root mat from claypan or B horizon ( $13-28$ in.). In loessal soil of $\mathrm{C}$ horizon (below $28 \mathrm{in}$.) root branching and weight of roots greatly increased. 
at 2 feet in depth. Moreover, branching of the roots was less pronounced in this horizon. Many of the roots penetrated the compact soil vertically through the columns (probably when they were quite moist), but they were also common in the crevices between them. Here they branched abundantly but mostly in the plane of the crack.

Beneath the solum in the $\mathrm{C}$ horizon of parent material the soil was both mellow and moist, and root branching greatly increased. This was below 28 inches. The yellowish loess, which was a silty clay loam, had a much smaller content of clay and a massive structure. There was an abundance of lime, often in small concretions. The $\mathrm{pH}$ value was $7 \cdot 5$. In this loessal horizon a third type of root distribution different from that in the $\mathrm{A}$ or $\mathrm{B}$ horizons accompanied the change in soil environment. The roots were often flattened on the faces of the small blocks, which cleaved in all directions. Thus, branching occurred in all planes. Although some of the cloddy masses were penetrated by roots, they were far more abundant on their surfaces. When this moist, soft loess was washed away, there remained a glistening white mass of roots with branches running out at all angles (fig. 9). Below a depth of 4 feet the parent loess contained more silt and less clay than above. This massive, friable loess, with vertical cracks every few inches, had no definite horizontal cleavage. The main roots followed the crevices where thin films of organic colloids had collected.

Claypan soils are not receptive to water. When dry, the shrinking of the clay results in deep, wide fissures through the claypan layer. It seems certain that much moisture is supplied to the $\mathrm{C}$ horizon by water running down these cracks. Some of this water also wets the bottom of the claypan layer as well as the parent material. Roots of bluestems and most other grasses cannot successfully penetrate through well-formed claypans in this area and hence do not thrive. Conversely, roots of wheat grass become adjusted to these soils. Often greater root development occurs below the claypan than within it.

In the present example root weight in grams at $0-6$ and 6-1 2 inches and then by feet was 10.74, 2.61, 2.1 7, 2.27, I.58, 0.78 , and 0.56 . This shows only a slight increase of materials in the third foot. But if the root weight at $16-28$ inches is compared with that at $28-40$ inches, there is an increase of $32 \%$ in weight in the upper foot of mellow loess soil over that in the lower foot of the claypan. Such differences have never been found by the writer except in other samples of wheat grass in claypan soils.

\section{Summary}

I. A modification of the new, monolith method of securing complete samples of an entire root system is illustrated. Blocks of soil 2.5 feet wide, 3 inches thick, and 3-6 feet in depth are taken from a vertical wall of a trench. The method permits a study of the intimate relations of roots and soil and of measuring root production quantitatively at various soil levels.

2. The roots of Andropogon furcatus were very heavy in climax prairie on Wabash silt loam (9I.I gm. per sample). They were uniformly distributed, decreased gradually in weight with depth, and extended downward 6 feet.

3. When Poa pratensis replaced Andropogon furcatus after several years of overgrazing, its root system was relatively light (55.6 gm.), entirely confined to the surface 3 feet, and had $89.9 \%$ of its 
weight in the surface foot of soil. In a similar pasture of $P$. pratensis and Bouteloua gracilis in (upland) Carrington silty clay loam, root weight was still less (28.2 gm.), and roots of $P$. pratensis were only 2 feet deep. Thus, susceptibility of bluegrass pastures to drought and to invasion by deeply rooted weeds is more readily comprehended.

4. Root distribution in bunch-grass prairie was remarkably uniform below a depth of 3 inches and not unlike that under sod-forming species. Root weight was only slightly concentrated beneath the bunches.

5. The broad monolith method often revealed the presence of widely spreading roots of Panicum virgatum and Andropogon furcatus at depths of 3-24 inches below adjacent stands of Poa pratensis. This indicated invasion of territory I 2-24 inches horizontally beyond that shown by the top and rhizomes in the surface soil. Such wide spreading of roots had not been recorded before in studies of native grasses in climax prairie.

6. Adaptation of the roots of Agropyron smithii to soils with claypans illustrates three distinct environments underground and remarkable soil-root relationships. A granular A horizon of mellow, moist soil resulted in a well-branched, heavy, normal development of roots. In the blocky, prismatic, very compact claypan beneath, roots were fewer, branching was poor, and roots penetrated the soil with difficulty. In the mellow, moist soil below the claypan, root branching greatly increased, occurred in all planes, and total weight of roots was a third greater in this more favorable environment. Such soils affect normal succession, since many climax species cannot thrive where they occur.

\section{LITERATURE CITED}

I. Weaver, J. E. The ecological relations of roots. Carn. Inst. Wash. Pub. 286. I9rg.

2. - - Root development in the grassland formation. Carn. Inst. Wash. Pub. 292. 1920.

3. - - - Root Development of Field Crops, pp. 255-261. McGraw-Hill, New York. I926.

4. Weaver, J. E., and Albertson, F. W. Resurvey of grasses, forbs, and underground plant parts at the end of the great drought. Ecol. Monog. 13:63-1 1 7. I943.

5. - - _ and - _- Nature and degree of recovery of grassland from the great drought of I933 to I940. Ecol. Monog. 14:393-479. I944.
6. Weaver, J. E., and Darland, R. W. Changes in vegetation and production of forage resulting from grazing lowland prairie. Ecology 29:1-29. 1948 .

7. - and- Quantitative study of root systems in different soil types. Science $110: 164^{-}$ I65. I949.

$\varepsilon \rightarrow-$. Soil-root relationships of certain native grasses in various soil types. Ecol. Monog. 19:303-338. 1949.

9. Weaver, J. E., and Zink, E. Annual increase of underground materials in three range grasses. Ecology 27: 115-1 27. 1946. 